\title{
Biomarkers of Infection: Are They Useful in the ICU?
}

\author{
Eva Heilmann, $\mathrm{MSc}^{1} \quad$ Claudia Gregoriano, $\mathrm{PhD}^{1} \quad$ Philipp Schuetz, MD, PhD, $\mathrm{MPH}^{1,2}$ \\ ${ }^{1}$ Medical University Department of Internal Medicine, Kantonsspital \\ Aarau, Aarau, Switzerland \\ 2 Faculty of Medicine, University of Basel, Switzerland \\ Address for correspondence Philipp Schuetz, MD, MPH, Medical \\ University Department of Internal Medicine, Kantonsspital Aarau, \\ Tellstrasse, CH-5001 Aarau, Switzerland \\ (e-mail: Philipp.Schuetz@unibas.ch).
}

Semin Respir Crit Care Med 2019;40:465-475.

\begin{abstract}
Biomarkers are increasingly used in patients with serious infections in the critical care setting to complement clinical judgment and interpretation of other diagnostic and prognostic tests. The main purposes of such blood markers are (1) to improve infection diagnosis (i.e., differentiation between bacterial vs. viral vs. fungal vs. noninfectious), (2) to help in the early risk stratification and thus provide prognostic information regarding the risk for mortality and other adverse outcomes, and (3) to optimize antibiotic tailoring to individual needs of patients ("antibiotic stewardship").

Especially in critically ill patients, in whom sepsis is a major cause of morbidity and mortality, rapid diagnosis is desirable to start timely and specific treatment.

Besides some biomarkers, such as procalcitonin, which is well established and has shown positive effects in regard to utilization of antimicrobials and clinical outcomes, there is a growing number of novel markers from different pathophysiological pathways, where the final proof of an added value to clinical judgment and ultimately clinical benefit to patients is still lacking.

$\begin{array}{ll}\text { Keywords } & \text { Without a doubt, the addition of blood biomarkers to clinical medicine has had a strong } \\ \text { - biomarker } & \text { impact on the way we care for patients today. Recent trials show that as an adjunct to } \\ \text { - ICU } & \text { other clinical and laboratory parameters these markers provide important information } \\ \text { - infection } & \text { about risks for bacterial infection and resolution of infection. Moreover, biomarkers can } \\ \text { - procalcitonin } & \text { help to optimize management of patients with serious illness in the intensive care unit, } \\ \text { - antibiotic } & \text { thereby offering more individualized treatment courses with overall improvements in } \\ \text { stewardship } & \text { clinical outcomes. }\end{array}$
\end{abstract}

The term "biomarker" or "biological marker" refers to a medical state observed from outside the patient-which can be measured accurately, objectively, and reproducibly. ${ }^{1}$ Thereby, it is any laboratory tool with the potential to better detect and characterize a disease, to simplify complex clinical algorithms, and to improve clinical problem solving. ${ }^{2}$ From a clinical perspective, a biomarker must complement the clinical judgment and the interpretation of other diagnostic and prognostic tests and add information that eventually improves patient care. An ideal biomarker should have fast kinetics and high sensitivity and specificity. Further, it should be identifiable fully automatically, should have a short turnaround time, and at best be available as a pointof-care test with low production costs. ${ }^{3}$

In the setting of critically ill patients with severe infections, there are three main areas where biomarkers can improve clinical management ( $\mathbf{- F i g . ~ 1 ) : ~ ( 1 ) ~ t o ~ i m p r o v e ~}$ infection diagnosis (i.e., differentiation between bacterial vs. viral vs. fungal infection vs. noninfectious) which may translate into better empiric treatment of the patient, (2) to help in the early risk stratification and thus provide prognostic information that may improve site-of-care decisions (e.g., early discharge or escalation of care), and (3) to optimize therapeutic decisions (e.g., in regard to antibiotic
Issue Theme Serious Infections in the ICU: Evolving Concepts in Management and Prevention; Guest Editors: Jean Chastre, MD, Charles-Edouard Luyt, MD, PhD, and Michel Wolff, MD
Copyright $\odot 2019$ by Thieme Medical Publishers, Inc., 333 Seventh Avenue, New York, NY 10001, USA.

Tel: +1(212) 584-4662.
DOI https://doi.org/ 10.1055/s-0039-1696689. ISSN 1069-3424. 


\section{Types of biomarkers}
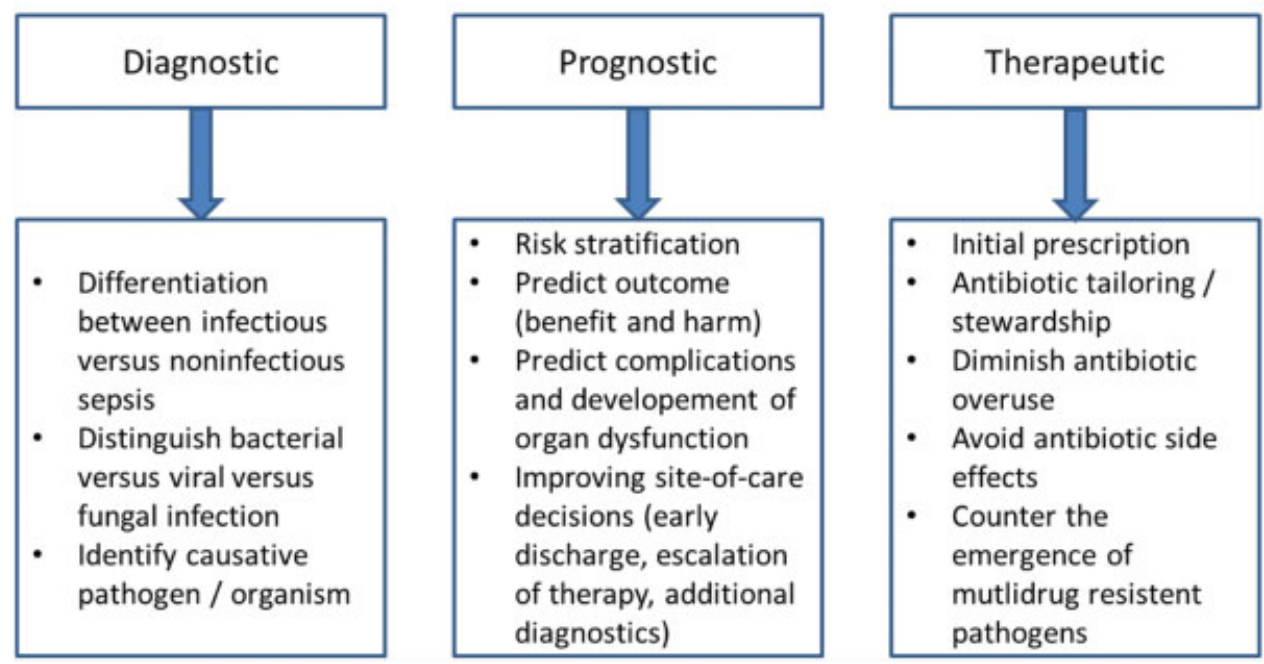

Fig. 1 Types of biomarkers and examples of their potential use.

tailoring to individual needs of patients, a term called "antibiotic stewardship"). 4,5

The aim of this narrative review is to summarize current concepts of biomarker use in the setting of serious infections in patients treated in the intensive care unit (ICU) regarding the diagnostic, prognostic, and therapeutic use.

\section{Diagnostic Biomarkers for Infections in the ICU}

Several reports indicate that sepsis is a leading cause of mortality and critical illness worldwide, ${ }^{6}$ particularly if the initial diagnosis is missed. Early and accurate diagnosis of sepsis and differentiation from noninfectious causes are crucial for rapidly starting fluid resuscitation and antibiotic treatment.

Sepsis has been characterized as a dysregulated reaction of the host to an infecting pathogen. Affected patients show heterogeneous symptoms, response to treatment, and outcomes. $^{3,6,7}$ Currently, no gold standard exists for detecting sepsis due to blood stream infection, which would be a key factor for targeted therapy and may improve survival. There are important limitations to the use of conventional diagnostic modalities such as blood cultures and inflammatory blood markers (i.e., C-reactive protein, white blood cells) in patients with clinical suspicion of infection and sepsis in the ICU setting. ${ }^{8}$

Physicians are thus often ambiguous regarding the necessity and timing of antimicrobial treatment, which can delay the appropriate treatment with negative clinical consequences.

Blood cultures, currently the most reliable diagnostic method for identification of pathogens, give important information about type of microorganism and susceptibility toward antibiotic treatment. However, only a small proportion of cultures turn positive and in 40 to $90 \%$ of patients with a suspected systematic infection, the culture does not grow any pathogens. ${ }^{9,10}$
For example, a large retrospective study from China found that of 2,829 blood cultures taken upon hospital admission, only $440(15.5 \%)$ came back positive. ${ }^{11}$ Further limitations of blood cultures include a long time to result, which in turn limits initial treatment decision making and contamination resulting in suboptimal specificity of results. These limitations call for additional tests to improve the diagnostic work-up of patients.

There are high hopes in novel technologies that may help to improve identification of pathogens including matrix-assisted laser desorption/ionization time-of-flight mass spectrometry (MALDI-TOF MS) and nucleic acid aptamers. ${ }^{12}$ These technologies are all pathogen directed aiming to identify the causative organism and potentially give some information about expected resistance. Typically, such novel approaches need lower amounts of pathogen DNA, which increases their sensitivity, but may limit specificity because false-positive resultsparticularly pathogens that are present in the blood stream but are not causing the disease-may occur more frequently.

Another approach to improve diagnostic work-up of patients is to look at host-response markers, which indirectly provide information about severity of infection and possibly type of pathogen. Compared with healthy individuals, peripheral blood cells in septic patients exhibit modified RNA transcripts in response to infection. ${ }^{3}$ Therefore, an emerging technology is gene expression profiling of peripheral blood cells, which simultaneously measures the expression of a large number of genes to generate a snapshot of host immune cell function. ${ }^{13,14}$ Pattern-recognition receptors on immune cells are activated by different pathogen-derived ligands, which results in the initiation of distinct sets of transcriptional programs. The resultant pattern of gene expression represents a transcriptional signature of a specific pathogen. Several studies have looked at gene expression profiling of peripheral blood cells as a means to improve diagnosis in patients with infection in the ICU. Early results are promising, ${ }^{15}$ but larger 
and more definite trials are needed to understand whether this technology will add to the clinical assessment of patients.

Not only gene expression profiling, but also the so-called proteomics and metabolomics profiling are subjects of current research. ${ }^{16}$ The objective of this technology is to identify protein and metabolic biomarkers being capable of differentiation infectious from noninfectious sepsis. ${ }^{3}$ Despite promising first results the use of these technologies is currently still limited by technical challenges, high costs, and lack of reproducibility.

The most widely studied host-directed marker is procalcitonin (PCT), a hormokine that is released in different tissues in the body in response to sepsis caused by bacterial infections via stimulation through cytokines (e.g., interleukin [IL]-1 $\beta$, tumor necrosis factor [TNF]- $\alpha$, and IL-6). ${ }^{17}$ Interestingly, interferon-gamma (INF- $\gamma$ ), a cytokine released in response to viral infections, reduces the upregulation of PCT. This results in a higher specificity of PCT for distinguishing bacterial from viral infection.

By means of PCT measurement, a specific pathogen cannot be detected, but the level of PCT may help estimate the probability of severe bacterial infections and thus the clinical relevance of a positive blood culture result. ${ }^{18}$
Yet, observational studies investigating the diagnostic accuracy of PCT for sepsis diagnosis yielded diverging results, which is mainly explained by differences in study populations and reference standard for infection used in the studies.

In 2007, a meta-analysis including 18 studies with 2,097 critically ill patients assessing PCT showed a median sensitivity and specificity of $71 \%$ as well as an area under the summary receiver operating characteristic curve (ROC) of 0.78 (95\% confidence interval [CI]: 0.73-0.83) and led to the conclusion that PCT could not distinguish infectious from noninfectious systemic inflammatory response syndrome (SIRS) with high certainty. ${ }^{19}$ A more recent meta-analysis including 30 high-quality studies and a total of 3,244 patients found that PCT in fact can differentiate effectively between sepsis and SIRS of noninfectious origin with an ROC curve of 0.85 (95\% CI: 0.81-0.88). ${ }^{20}$ The later study used blood cultures as the reference standard.

Recently, an international expert consensus was published, recommending PCT cutoff levels in critically ill patients to estimate the probability of bacterial infection and therefore improving initial clinical assessment (-Fig. 2). ${ }^{21}$ Instead of one cutoff, these guidelines recommended cutoff ranges with higher and lower positive and negative predictive values for sepsis.

\section{Patients with severe illness in ICU
(Defined by setting specific scores (e.g. qSOFA, SOFA, APACHE)}

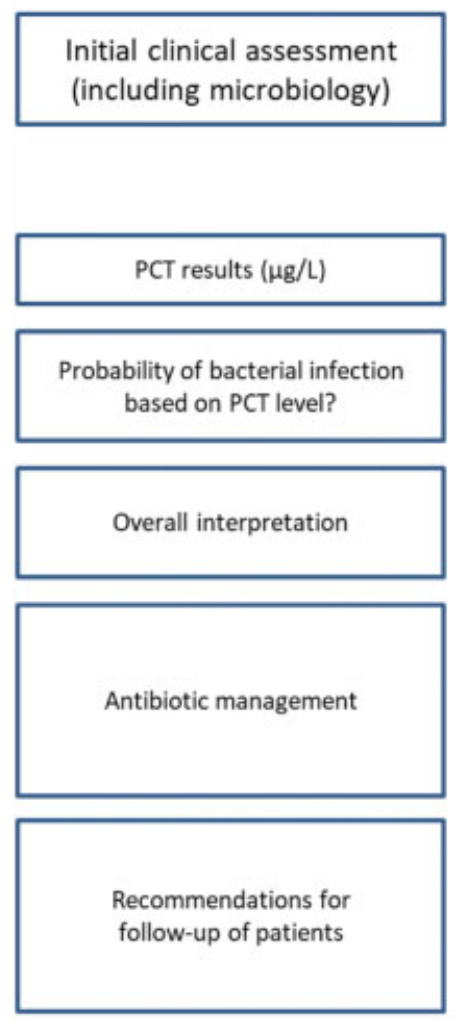

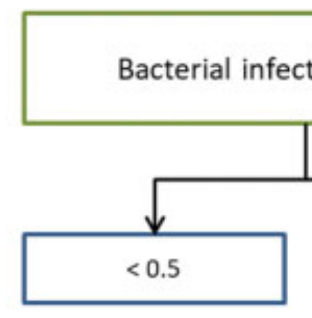
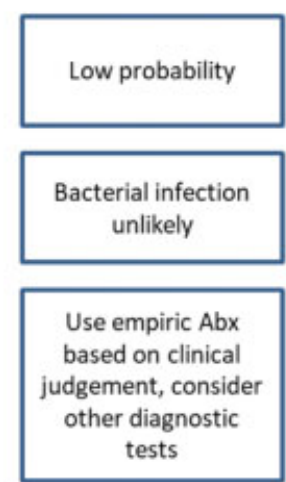

Use PCT within 24 -

$48 \mathrm{~h}$ for monitoring and discontinuation of $A b x$ if $P C T$ is still < $0.5 \mu \mathrm{g} / \mathrm{L}$
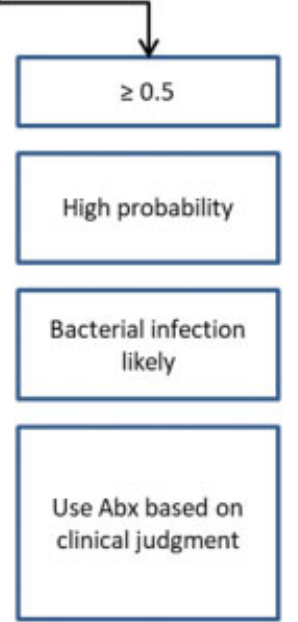

Use PCT every 24

$48 \mathrm{~h}$ for monitoring and discontinuation of $\mathrm{Abx}$ if $\mathrm{PCT}<0.5$ $\mu \mathrm{g} / \mathrm{L}$ or drop by $80 \%$

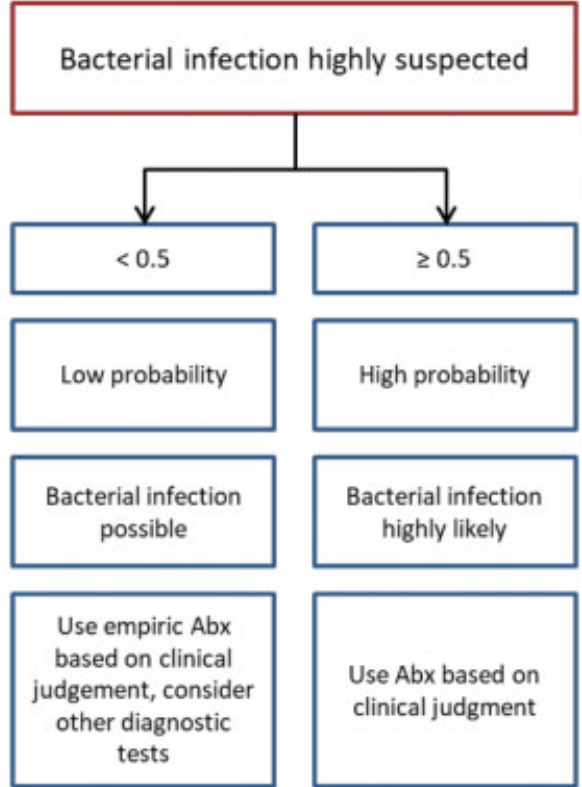

Use PCT every 24$48 \mathrm{~h}$ for monitoring and discontinuation of $\mathrm{Abx}$ if $\mathrm{PCT}<0.5$ $\mu \mathrm{g} / \mathrm{L}$ or drop by $80 \%$

Fig. 2 PCT use in patients with severe illness in the ICU. Note: caution in patients with immunosuppression (including HIV), cystic fibrosis, pancreatitis, trauma, pregnancy, high volume transfusion, malaria; PCT-guided stewardship should not be applied to patients with chronic infections (e.g., abscess, osteomyelitis, endocarditis). ICU, intensive care unit; PCT, procalcitonin. (Adapted from Schuetz et al. ${ }^{21}$ ) 
In this context it is important to emphasize that any diagnosis should not only be based on a specific biomarker but rather in conjunction with the pretest probability based on the clinical assessment and other laboratory results.

\section{Prognostic Biomarkers Assessing Risk in Infected Patients in the ICU}

The second main purpose of biological markers in the setting of severe infection in the ICU is to assess a patient's individual risk profile and therefore to predict outcome. Accurate disease severity assessment and clinical course prediction assist patients, families as well as caregivers in setting realistic expectations regarding the illness. Risk stratification and prognostication are also important prerequisites for appropriately applying health care resources and therapeutic options. It may help to identify patients who would likely benefit the most from targeted and extensive therapy without causing unnecessary harm.

The recently updated criteria for the definition of sepsis based on the Sequential Organ Failure Assessment (SOFA) score $\geq 2$ in the presence of infection showed a high prognostic accuracy for in-hospital mortality in the ICU. ${ }^{6,22}$ Still, SOFA is a complex tool composed of 11 different clinical and laboratory markers which limit its use especially outside the ICU.

Using clinical risk scores, such as APACHE or SAPS II, for the purpose of prognostication, is partly also limited by practicality issues and these scores are only validated when admission values are used. ${ }^{23,24}$

Thus, there is interest in predictive use of newly available biomarkers that are objectively and rapidly measurable, respond to clinical recovery, and add relevant, reliable, and real-time information. ${ }^{25}$ Interestingly, a recent retrospective analysis using data from 63,858 patients in three observational cohorts suggests that patients with sepsis can be further phenotyped based on biomarkers of host response, which has consequences for future treatment approaches. ${ }^{26}$ The authors proposed four novel sepsis phenotypes ( $\alpha, \beta, \gamma$, and $\delta$ ) with different demographics, laboratory values, and patterns of organ dysfunction, which correlated with biomarkers and mortality. In a simulation, patient outcomes related to the treatments were sensitive to changes in the distribution of these phenotypes.

Several biomarkers have been proposed to improve prognostic work-up of sepsis patients. These include markers based on the complex pathophysiology of sepsis, characterized by activating pro- and anti-inflammatory responses combined with reactions and modification in nonimmunological pathways (e.g., cardiovascular, neuronal, renal, coagulation, and metabolism). Hence, numerous biomarkers have been identified and examined in regard to their prognostic value (-Fig. 3) ${ }^{6,27}$

- Table 1 shows an overview of some prognostic markers, which may help in the risk assessment of septic patients.

One of the commonly used biomarkers is serum lactate, a surrogate of tissue hypoperfusion and metabolic stress in septic patients. Higher lactate levels are not only associated with increased mortality, ${ }^{28}$ but mortality rates can also significantly be reduced by lactate-guided resuscitation. ${ }^{29,30}$ Lactate kinetics are thus of prognostic significance ${ }^{31}$ and repeated measurements within 2 to 4 hours are recommended by the Surviving Sepsis Campaign if initial lactate is elevated ( $>2 \mathrm{mmol} / \mathrm{L}$ ).

Kinetics of PCT over time has also been shown to improve monitoring of the critically ill patient with sepsis and respiratory infection. ${ }^{32-38}$ Indeed, PCT kinetics have shown prognostic implications, as decreasing values correlate with good outcomes, while increasing values correlate with adverse outcomes including mortality. ${ }^{39-41}$ A Finnish investigation found PCT concentrations to be higher in more severe cases of advanced sepsis, but a substantial decrease in concentration was a more important survival predictor than were absolute values. ${ }^{40}$

A derivation-validation study using retrospective data from two independent U.S. critical care institutions revealed a high prognostic value when considering the 72-hour PCT kinetics for sepsis mortality. ${ }^{42}$

In the derivation and validation cohorts, a PCT decrease over 72 hours of $>80 \%$ had a negative predictive value of 90 and $91 \%$ to exclude ICU mortality, probably helping to identify individuals at reduced risk, who thus are good candidates for therapy de-escalation or early ICU discharge. Conversely, a nondecrease or increase of PCT within this timeframe had a positive predictive value of around 35 to $50 \%$, potentially flagging patients who are at high mortality risk and thus are likely to require treatment escalation. These results were also confirmed in an U.S. Food and Drug Administration (FDA) study among different United States based hospitals (MOSES study). ${ }^{43}$

However, it has been challenging to understand whether prognostic information also results in improved clinical outcomes of patients. Herein, a large interventional trial did not show a mortality benefit when PCT was used to escalate the diagnostic and therapeutic management. ${ }^{39}$

Yet, patients in the intervention arm had more complications (e.g., renal impairment, ventilation days) due to prolonged antibiotic therapy and more diagnostic studies.

Compared with other medical fields such as oncology or cardiovascular medicine, the clinical use of prognostic biomarkers in critically ill patients with sepsis is still ill defined. Besides markers of infection and inflammation, there is a wide range of markers for organ dysfunction that could be used for monitoring specific pathways and inform about the physiopathology, thereby improving risk stratification and prognostication. Regarding the complex pathophysiology of sepsis, it is questionable if one optimal biomarker for prognosis will ever be found. Combination of different markers from distinct pathways with clinical parameters may have more potential to accurately predict outcomes. $^{44}$

Further research is warranted to identify sets of biomarkers reflecting changes in patient's physiology with sepsis that can be obtained reliably, simply, and cost-efficiently, leading to an even more personalized medicine. 


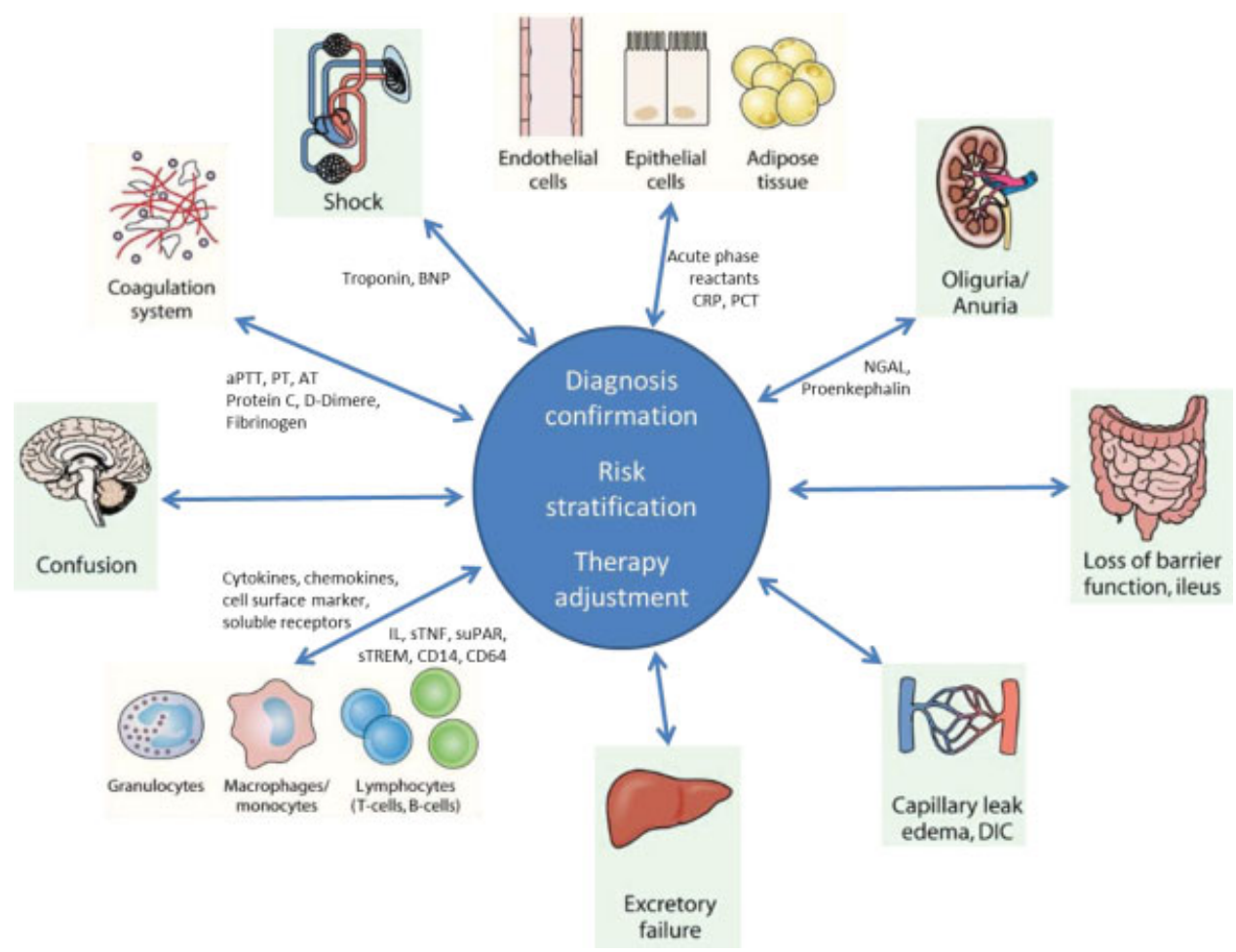

Fig. 3 Immunological and nonimmunological response through biomarkers and mediators to a bacterial pathogen and the resulting multiorgan dysfunction. Biomarkers and their impact on organ function can help confirm a diagnosis, to assess the patients risk for mortality and morbidity as well as to tailor individual treatment. Once the source of infection is controlled due to adequate treatment, organ function can recover and biomarker abnormalities normalize. Otherwise biomarker abnormalities persist and leading to progredient organ failure and maybe death. aPTT, activated partial thromboplastin time; AT, antithrombin; BNP, B-type natriuretic peptide; CD14 and CD64, integral membrane glycoproteins; CRP, C-reactive protein; DIC, disseminated intravascular coagulation; IL, interleukin; NGAL, neutrophil gelatinase-associated lipocalin; PCT, procalcitonin; PT, prothrombin time; sTNF, soluble tumor necrosis factor; sTREM, soluble triggered receptor expressed on myeloid cells; suPAR, soluble urokinase type plasminogen activator receptor. (Adapted from Reinhart K. et al. New approaches to sepsis: molecular diagnostics and biomarkers. Clin Microbiol Rev 2012;25(4):609-634.)

\section{Therapeutic Biomarkers for Antibiotic Stewardship in the ICU}

Appropriate empirical antibiotic therapy is a cornerstone of therapy and highly effective for reducing mortality and morbidity in community-acquired pneumonia and sepsis. ${ }^{45,46}$

Still, antibiotic overuse, mainly due to long treatment durations and use of antibiotics in viral infections, puts individual patients to the risk of adverse drug reactions with no therapeutic benefit. Antibiotic overuse is also strongly associated with the emergence of bacterial resistance. ${ }^{47,48}$

Clinical signs and symptoms have low sensitivity and specificity to differentiate self-limited and mild viral infections from more severe bacterial disease. Due to this uncertainty, physicians are often reluctant to abstain from or limit the duration of antibiotic therapy based only on clinical grounds. Using blood biomarkers that can accurately indicate the risk for bacterial infection and can be measured in a short time after admission of the patient can help fill this gap. Such a strategy not only leads to a lower antibiotic overuse, but also potentially lowers antibiotics-associated side effects and mortality, and treatment failure. ${ }^{49,50}$

In this context, PCT has gained much attention lately. Its advantages as well as its limitations are well known and its use to guide antibiotic treatment recently has been approved by FDA, ${ }^{21}$ based on a series of randomized trials showing efficacy and safety.

The efficacy and safety of PCT-guided decision-marking regarding antibiotics has been demonstrated in several randomized controlled trials including infections of varying severity in different clinical settings from primary care to the ICU. ${ }^{50-52}$ Particularly in the ICU, the issue of safety is of outmost importance because patients' baseline risk is high.

Appropriate empirical antibiotic therapy is a cornerstone of therapy and highly effective for reducing mortality and morbidity in community-acquired pneumonia and sepsis. ${ }^{45,46}$

One of the first randomized "proof of concept" trials studying the effect and safety of PCT-guided therapy in patients with sepsis requiring intensive care showed a reduced exposure to antibiotics without causing any harm or negative outcome. $^{36}$ Subsequent several large, multicenter trials, including the PRORATA trial ${ }^{53}$ and the Stop Antibiotics on Procalcitonin Guidance Study (SAPS), ${ }^{49}$ validated the use of PCT-guided therapy and found PCT to be helpful in reducing antibiotic exposure by reducing the duration of treatment. Importantly, in any clinical scenario where the probability for bacterial infection is a priori high and time to appropriate treatment is crucial, such as sepsis patients in the ICU, initial antibiotics should be used and PCT is mainly used for treatment cessation based on its kinetics. 
Table 1 Overview of some biomarkers and their prognostic value regarding risk assessment of critically ill septic patients

\begin{tabular}{|c|c|c|c|c|c|}
\hline Organ & Biomarker & $\begin{array}{l}\text { Clinical } \\
\text { value }\end{array}$ & Physiology & $\begin{array}{l}\text { Recent } \\
\text { studies }\end{array}$ & Comment/limitations \\
\hline \multirow[t]{4}{*}{ Metabolic } & Procalcitonin (PCT) & $\begin{array}{l}\text { Diagnostic } \\
\text { Prognostic }\end{array}$ & $\begin{array}{l}\text { - } \text { PCT expression is } \\
\text { upregulated in response } \\
\text { to bacterial infection } \\
\text { - } \text { PCT expression is } \\
\text { reduced in response to } \\
\text { viral infection }\end{array}$ & $21,39,40,42,43$ & $\begin{array}{l}\text { - Adjunct to clinical } \\
\text { judgment to assess risk for } \\
\text { bacterial infection } \\
\text { - Kinetics over time have } \\
\text { prognostic implications } \\
\text { - PCT-guided antibiotic } \\
\text { stewardship reduces } \\
\text { antibiotic exposure and } \\
\text { shows evidence for } \\
\text { improved survival } \\
\text { - Limited data in immuno- } \\
\text { suppressed patients } \\
\text { - Increased PCT also in } \\
\text { noninfectious conditions } \\
\text { (trauma, surgery, C-cell } \\
\text { carcinoma) }\end{array}$ \\
\hline & $\begin{array}{l}\text { Adrenomedullin } \\
\text { (ADM), pro-adreno- } \\
\text { medullin (Pro-ADM) }\end{array}$ & Prognostic & $\begin{array}{l}\text { - ADM/Pro-ADM is } \\
\text { upregulated in different } \\
\text { tissues in several } \\
\text { conditions (SIRS, shock, } \\
\text { cellular hypoxia, oxida- } \\
\text { tive stress, myocardial } \\
\text { injury; remarkably high } \\
\text { levels in sepsis) }\end{array}$ & $60-63$ & $\begin{array}{l}\text { - Strict association between } \\
\text { high levels of biological } \\
\text { ADM/Pro-ADM and disease } \\
\text { severity, organ failure and } \\
\text { mortality } \\
\text { - Pro-ADM kinetics may be } \\
\text { helpful for risk assessment } \\
\text { of treatment failure }\end{array}$ \\
\hline & $\begin{array}{l}\text { C-reactive protein } \\
(\mathrm{CRP})\end{array}$ & $\begin{array}{l}\text { Diagnostic } \\
\text { Prognostic }\end{array}$ & $\begin{array}{l}\text { - Stimulated by cytokines } \\
\text { - Liver cells synthesize CRP } \\
\text { after onset of inflamma- } \\
\text { tion or damage (within } \\
6-8 \mathrm{~h} \text {, peak 36-50 h) }\end{array}$ & $64-66$ & $\begin{array}{l}\text { - Established marker of } \\
\text { infection and inflammation } \\
\text { - Low specificity }\end{array}$ \\
\hline & Lactate & Prognostic & $\begin{array}{l}\text { - Increased levels in } \\
\text { hypoxia, stress, and } \\
\text { critical illness as a } \\
\text { product of anaerobic } \\
\text { glycolysis }\end{array}$ & $29,31,67$ & $\begin{array}{l}\text { - Prognostic predictor of } \\
\text { mortality }\end{array}$ \\
\hline \multirow[t]{2}{*}{ Cardial } & $\begin{array}{l}\text { Highly sensitive } \\
\text { troponin }\end{array}$ & Prognostic & $\begin{array}{l}\text { - Released by damaged } \\
\text { myocytes } \\
\text { - Sensitive and specific } \\
\text { marker of myocardial } \\
\text { injury }\end{array}$ & 68,69 & $\begin{array}{l}\text { - Elevated troponin level in } \\
\text { septic patients is a } \\
\text { predictor of mortality }\end{array}$ \\
\hline & $\begin{array}{l}\text { B-type natriuretic } \\
\text { peptide (BNP) }\end{array}$ & Prognostic & $\begin{array}{l}\text { - Released from } \\
\text { cardiomyocytessecondary } \\
\text { to volume or pressure } \\
\text { overload, ischemia, } \\
\text { necrosis, remodeling }\end{array}$ & $70-72$ & $\begin{array}{l}\text { - Controversial data } \\
\text { - Limited prognostic value } \\
\text { for mortality }\end{array}$ \\
\hline \multirow[t]{2}{*}{ Renal } & $\begin{array}{l}\text { Neutrophil gelati- } \\
\text { nase-associated lip- } \\
\text { ocalin (NGAL) }\end{array}$ & $\begin{array}{l}\text { Diagnostic } \\
\text { Prognostic }\end{array}$ & $\begin{array}{l}\text { - Released by neutrophils } \\
\text { in response to bacterial } \\
\text { components } \\
\text { - Secreted by injured renal } \\
\text { tubules }\end{array}$ & $73-76$ & $\begin{array}{l}\text { - Data inconsistent } \\
\text { - Controversial specific value } \\
\text { because of its extra-renal } \\
\text { production (confounder) }\end{array}$ \\
\hline & $\begin{array}{l}\text { Proenkephalin } \\
\text { (PENK) }\end{array}$ & $\begin{array}{l}\text { Diagnostic } \\
\text { Prognostic }\end{array}$ & $\begin{array}{l}\text { - Negatively correlated } \\
\text { with glomerular } \\
\text { filtration rate } \\
\text { - In case of acute kidney } \\
\text { dysfunction proenke- } \\
\text { phalin increases more } \\
\text { quickly than creatinine }\end{array}$ & $77-80$ & $\begin{array}{l}\text { - Association with acute kid- } \\
\text { ney injury in septic patients } \\
\text { - Predictive of short-term } \\
\text { mortality }\end{array}$ \\
\hline
\end{tabular}


Table 1 (Continued)

\begin{tabular}{|c|c|c|c|c|c|}
\hline Organ & Biomarker & $\begin{array}{l}\text { Clinical } \\
\text { value }\end{array}$ & Physiology & $\begin{array}{l}\text { Recent } \\
\text { studies }\end{array}$ & Comment/limitations \\
\hline Coagulation & $\begin{array}{l}\text { Disseminated } \\
\text { intravascular } \\
\text { coagulation (DIC) }\end{array}$ & Prognostic & $\begin{array}{l}\text { - DIC is an hemorrhagic- } \\
\text { thrombotic state } \\
\text { triggered by proinflam- } \\
\text { matory cytokines in } \\
\text { response to several } \\
\text { diseases (sepsis, trauma, } \\
\text { cancer) }\end{array}$ & $81-83$ & $\begin{array}{l}\text { - DIC is associated with poor } \\
\text { prognosis } \\
\text { - Coagulation dysregulation } \\
\text { is best interpreted through } \\
\text { repeated measurements }\end{array}$ \\
\hline \multirow[t]{2}{*}{ Cell marker } & $\begin{array}{l}\text { Presepsin } \\
\text { (soluble CD14) }\end{array}$ & $\begin{array}{l}\text { Diagnostic } \\
\text { Prognostic }\end{array}$ & $\begin{array}{l}\text { - Expressed on monocytes } \\
\text { and macrophages in } \\
\text { response to lipopolysac- } \\
\text { charide stimulation } \\
\text { (within 2-3 h) }\end{array}$ & $\begin{array}{l}84-87 \\
\end{array}$ & $\begin{array}{l}\text { - Conflicting data, its clinical } \\
\text { utility needs to be further } \\
\text { evaluated }\end{array}$ \\
\hline & CD 64 & $\begin{array}{l}\text { Diagnostic } \\
\text { Prognostic }\end{array}$ & $\begin{array}{l}\text { - During systemic } \\
\text { inflammation circulating } \\
\text { monocytes and } \\
\text { polymorphic cells } \\
\text { increase expression of } \\
\text { CD64 (within 2-6 h) } \\
\text { - Levels decrease within } \\
48 \mathrm{~h} \text { after removal of the } \\
\text { initial stimulus }\end{array}$ & $7,88-90$ & $\begin{array}{l}\text { - Reviews consistently } \\
\text { demonstrated good } \\
\text { diagnostic performance, } \\
\text { but included studies were } \\
\text { heterogeneous and defined } \\
\text { sepsis differently } \rightarrow \text { further } \\
\text { evaluation is warranted } \\
\text { - Lower CD64 expression } \\
\text { levels are an indicator of } \\
\text { better prognosis }\end{array}$ \\
\hline \multirow[t]{2}{*}{ Receptor } & $\begin{array}{l}\text { Urokinase type } \\
\text { plasminogen } \\
\text { activator receptor } \\
\text { (soluble) (suPAR) }\end{array}$ & Prognostic & $\begin{array}{l}\text { - Upregulated and } \\
\text { released from mono- } \\
\text { cytes and T-lymphocytes } \\
\text { in response to bacterial } \\
\text { components and inflam- } \\
\text { matory cytokines }\end{array}$ & $7,91-93$ & $\begin{array}{l}\text { - Prognostic value for } \\
\text { mortality in critically ill } \\
\text { patients, including septic } \\
\text { patients }\end{array}$ \\
\hline & $\begin{array}{l}\text { Triggering receptor } \\
\text { expressed on } \\
\text { myeloid cells } \\
\text { TREM-1 (soluble) }\end{array}$ & Prognostic & $\begin{array}{l}\text { - Upregulated in the pres- } \\
\text { ence of bacteria or fungi; } \\
\text { but also in inflammatory } \\
\text { bowel disease, cancer, } \\
\text { and atherosclerosis }\end{array}$ & $7,94,95$ & $\begin{array}{l}\text { - Poor diagnostic marker } \\
\text { - Predictive biomarker for } \\
\text { the } 28 \text {-day mortality in } \\
\text { septic patients }\end{array}$ \\
\hline
\end{tabular}

While much work has been done for patients with respiratory infections, ${ }^{38,50}$ a recent meta-analysis, including 11 trials and 4,482 patients, investigating the effects of PCT use in patients with sepsis treated in the ICU demonstrated a significant reduction in mean treatment duration (from 10.4 to 9.3 days, $p=0.001$ ). Interestingly, the mortality rate in PCT-guided patients was also significantly lower compared with the control group ( 21.1 vs. $23.7 \%, p=0.03) .{ }^{54}$ Similar effects were also noted in subgroup analyses stratified by Sepsis-3 definition, severity of sepsis, presence of renal shock, renal failure and type of infection. These positive effects may be explained by a lower risk for antibiotic side effects with PCT-guided care. Also, the prognostic information derived from PCT kinetics may influence therapeutic decisions and prompt additional diagnostic assessment. ${ }^{55}$

Consistent with the results mentioned above, another meta-analysis studying PCT use in septic patients with positive blood cultures found a significantly shorter duration of antibiotic therapy for PCT-guided patients ( -2.86 days). Additionally, a trend toward a lower mortality in the intervention group was observed ( 16.6 vs. $20.0 \%, p=0.263$ ). ${ }^{56}$

In contrast to the available evidence regarding PCT-guided antibiotic de-escalation, therapy escalation based on PCT con- centrations cannot be recommended. A large interventional trial testing the hypothesis that therapy escalation in septic patients in whom PCT did not decrease appropriately would improve outcomes did not reveal a benefit for PCT-guided patients. $^{39}$

Despite the current body of evidence for PCT-guided antibiotic discontinuation, a commonly accepted clinical algorithm in critically ill patients was long lacking, which in turn limited a more widespread use of PCT. ${ }^{21}$ Still, PCT protocols used in the different trials were all somewhat similar and based on a similar intuitive concept: in patients with suspicion of sepsis, initial antibiotics were recommended based on clinical grounds, and PCT kinetics over time were used for recommendations regarding early discontinuation of antibiotic therapy. ${ }^{51}$ Thereby, PCT cutoffs of $<0.5 \mathrm{ng} / \mathrm{mL}$ or a decrease of 80 to $90 \%$ from the peak level were used to indicate resolution of illness and stopping of treatment in case the clinical course was also favorable. An international expert group recently also published a consensus algorithm for PCT use in patients with suspected bacterial infection and came to similar conclusions (-Fig. 2).21 Importantly, this algorithm has been tested in different interventional trials, which all documented significantly reduced antibiotic exposure and no excess mortality or 
increase in adverse event rates. However, adherence rates to PCT protocols were variable, particularly for ICU trials. ${ }^{36,37}$

\section{Practical Considerations When Implementing Procalcitonin Testing}

Decisions regarding antibiotic use in an individual patient are complex and should be based on several considerations including the pretest probability for bacterial infection. The pretest probability can be assessed by means of clinical examinations and the results from microbiological tests.

-Fig. 2 provides practical guides for a rational use of PCT in high-risk settings in conjunction with the clinical assessment including interpretation of PCT and recommendations for antibiotic use. ${ }^{21,57}$

To optimize antibiotic stewardship, implementation of supplemental educational programs would be useful. In the interventional noninferiority proACT trial, no reduction of antibiotic prescription or treatment duration among patients with suspected lower respiratory tract infection in the emergency department could be observed. ${ }^{58}$ Indeed, the adherence rate to the PCT protocol was low, illustrating lack of experience with PCT use and its interpretation in the clinical context as well as uncertainty regarding efficacy and safety of this approach. Therefore, frequent education in the context of an antibiotic stewardship may help physicians to gain more confidence in dealing with PCT measurements and improve patient care. ${ }^{21}$ This hypothesis is supported by the results of the retrospective cohort study by Broyles and colleagues. By means of education-based antibiotic stewardship, including the use of PCT measurements, lower rates of antibiotic prescriptions as well as reduced resistance rates were found. Additionally, this was associated with an improved outcome (e.g., lower readmission rates, shorter length of stay, less Clostridium difficile infections $).{ }^{59}$

\section{Limitations of Procalcitonin}

Most PCT studies were done in patients with respiratory infections or sepsis and there are only limited data in immunosuppressed patients including those with human immunodeficiency virus (HIV) and patients with cystic fibrosis, pancreatitis, trauma, pregnancy, and high volume transfusion. Moreover, some noninfectious conditions such as C-cell carcinoma or trauma cause systemic inflammation and also affect PCT levels. Furthermore, it is not recommended to apply PCT-guided stewardship in patients with chronic infections such as osteomyelitis or endocarditis as observational studies have not shown positive results and interventional research is largely lacking. ${ }^{31}$

\section{Conclusions and Outlook}

Biomarkers from distinct pathophysiological pathways are increasingly being used in patients with serious infections in the critical care setting to improve patient care, particularly for improved infection diagnosis, for early risk stratification, and to optimize antibiotic tailoring to individual needs of patients. In the critical care setting, rapid diagnosis is important to start the right medication for the right patient in a timely fashion, thereby reducing mortality and morbidity. Several biomarkers hold great promise to further improve patient management by providing diagnostic, prognostic, and therapeutic information. While some markers, such as PCT, are well established and showed positive effects in regard to utilization of antimicrobials and clinical outcomes in interventional trials, many other markers have not been well studied except for observational studies. Thus, the final proof of an added value to clinical judgment and ultimately clinical benefit to patients is still lacking. Biomarkers had a strong impact on clinical medicine and have changed the way we care for patients today. Still, further research is needed to explore the optimal use of biomarkers in combination with pathogen-directed tests.

\section{Financial Disclosures}

Prof. Schuetz reports receiving grants from bioMerieux, Thermo Fisher, and Roche Diagnostics (paid to the Institution).

\section{References}

1 Strimbu K, Tavel JA. What are biomarkers? Curr Opin HIV AIDS 2010;5(06):463-466

2 Schuetz P, Aujesky D, Müller C, Müller B. Biomarker-guided personalised emergency medicine for all - hope for another hype? Swiss Med Wkly 2015;145:w14079

3 van Engelen TSR, Wiersinga WJ, Scicluna BP, van der Poll T. Biomarkers in Sepsis. Crit Care Clin 2018;34(01):139-152

4 Schuetz P, Christ-Crain M, Müller B. Procalcitonin and other biomarkers to improve assessment and antibiotic stewardship in infections-hope for hype? Swiss Med Wkly 2009;139(23-24): 318-326

5 Schuetz P, Raad I, Amin DN. Using procalcitonin-guided algorithms to improve antimicrobial therapy in ICU patients with respiratory infections and sepsis. Curr Opin Crit Care 2013;19 (05):453-460

6 Singer M, Deutschman CS, Seymour CW, et al. The Third International Consensus Definitions for Sepsis and Septic Shock (Sepsis3). JAMA 2016;315(08):801-810

7 Larsen FF, Petersen JA. Novel biomarkers for sepsis: a narrative review. Eur J Intern Med 2017;45:46-50

8 Sager R, Kutz A, Mueller B, Schuetz P. Procalcitonin-guided diagnosis and antibiotic stewardship revisited. BMC Med 2017; 15(01):15

9 Laukemann S, Kasper N, Kulkarni P, et al. Can we reduce negative blood cultures with clinical scores and blood markers? Results from an observational cohort study. Medicine (Baltimore) 2015; 94(49):e2264

10 Vincent JL, Sakr Y, Sprung CL, et al; Sepsis Occurrence in Acutely Ill Patients Investigators. Sepsis in European intensive care units: results of the SOAP study. Crit Care Med 2006;34(02):344-353

11 Yu Y, Li XX, Jiang LX, et al. Procalcitonin levels in patients with positive blood culture, positive body fluid culture, sepsis, and severe sepsis: a cross-sectional study. Infect Dis (Lond) 2016;48 (01):63-69

12 Mitsuma SF, Mansour MK, Dekker JP, et al. Promising new assays and technologies for the diagnosis and management of infectious diseases. Clin Infect Dis 2013;56(07):996-1002

13 Ozsolak F, Milos PM. RNA sequencing: advances, challenges and opportunities. Nat Rev Genet 2011;12(02):87-98 
14 Ozsolak F, Milos PM. Single-molecule direct RNA sequencing without cDNA synthesis. Wiley Interdiscip Rev RNA 2011;2 (04):565-570

15 Davenport EE, Burnham KL, Radhakrishnan J, et al. Genomic landscape of the individual host response and outcomes in sepsis: a prospective cohort study. Lancet Respir Med 2016;4(04):259-271

16 Zurfluh S, Baumgartner T, Meier MA, et al. The role of metabolomic markers for patients with infectious diseases: implications for risk stratification and therapeutic modulation. Expert Rev Anti Infect Ther 2018;16(02):133-142

17 Linscheid P, Seboek D, Schaer DJ, Zulewski H, Keller U, Müller B. Expression and secretion of procalcitonin and calcitonin generelated peptide by adherent monocytes and by macrophage-activated adipocytes. Crit Care Med 2004;32(08):1715-1721

18 Cuquemelle E, Soulis F, Villers D, et al; A/H1N1 REVA-SRLF Study Group. Can procalcitonin help identify associated bacterial infection in patients with severe influenza pneumonia? A multicentre study. Intensive Care Med 2011;37(05):796-800

19 Tang BM, Eslick GD, Craig JC, McLean AS. Accuracy of procalcitonin for sepsis diagnosis in critically ill patients: systematic review and meta-analysis. Lancet Infect Dis 2007;7(03):210-217

20 Wacker C, Prkno A, Brunkhorst FM, Schlattmann P. Procalcitonin as a diagnostic marker for sepsis: a systematic review and metaanalysis. Lancet Infect Dis 2013;13(05):426-435

21 Schuetz P, Beishuizen A, Broyles M, et al. Procalcitonin (PCT)guided antibiotic stewardship: an international experts consensus on optimized clinical use. Clin Chem Lab Med 2019;57(09): $1308-1318$

22 Raith EP, Udy AA, Bailey M, et al; Australian and New Zealand Intensive Care Society (ANZICS) Centre for Outcomes and Resource Evaluation (CORE). Prognostic accuracy of the SOFA score, SIRS criteria, and qSOFA score for in-hospital mortality among adults with suspected infection admitted to the intensive care unit. JAMA 2017;317(03):290-300

23 Dellinger RP, Carlet JM, Masur H, et al; Surviving Sepsis Campaign Management Guidelines Committee. Surviving Sepsis Campaign guidelines for management of severe sepsis and septic shock. Crit Care Med 2004;32(03):858-873

24 Dellinger RP, Levy MM, Carlet JM, et al; International Surviving Sepsis Campaign Guidelines Committee; American Association of Critical-Care Nurses; American College of Chest Physicians; American College of Emergency Physicians; Canadian Critical Care Society; European Society of Clinical Microbiology and Infectious Diseases; European Society of Intensive Care Medicine; European Respiratory Society; International Sepsis Forum; Japanese Association for Acute Medicine; Japanese Society of Intensive Care Medicine; Society of Critical Care Medicine; Society of Hospital Medicine; Surgical Infection Society; World Federation of Societies of Intensive and Critical Care Medicine. Surviving Sepsis Campaign: international guidelines for management of severe sepsis and septic shock: 2008. Crit Care Med 2008;36(01): 296-327

25 Schuetz P, Wolbers M, Christ-Crain M, et al; ProHOSP Study Group. Prohormones for prediction of adverse medical outcome in community-acquired pneumonia and lower respiratory tract infections. Crit Care 2010;14(03):R106

26 Seymour CW, Kennedy JN, Wang S, et al. Derivation, validation, and potential treatment implications of novel clinical phenotypes for sepsis. JAMA 2019;321(20):2003-2017

27 Pierrakos C, Vincent JL. Sepsis biomarkers: a review. Crit Care 2010;14(01):R15

28 Nichol AD, Egi M, Pettila V, et al. Relative hyperlactatemia and hospital mortality in critically ill patients: a retrospective multicentre study. Crit Care 2010;14(01):R25

29 Jansen TC, van Bommel J, Schoonderbeek FJ, et al; LACTATE study group. Early lactate-guided therapy in intensive care unit patients: a multicenter, open-label, randomized controlled trial. Am J Respir Crit Care Med 2010;182(06):752-761
30 Lyu X, Xu Q, Cai G, Yan J, Yan M. Efficacies of fluid resuscitation as guided by lactate clearance rate and central venous oxygen saturation in patients with septic shock [in Chinese]. Zhonghua Yi Xue Za Zhi 2015;95(07):496-500

31 Vincent JL, Quintairos E Silva A, Couto LJr, Taccone FS. The value of blood lactate kinetics in critically ill patients: a systematic review. Crit Care 2016;20(01):257

32 Theodorou VP, Papaioannou VE, Tripsianis GA, et al. Procalcitonin and procalcitonin kinetics for diagnosis and prognosis of intravascular catheter-related bloodstream infections in selected critically ill patients: a prospective observational study. BMC Infect Dis 2012;12:247

33 Coelho LM, Salluh JI, Soares M, et al. Patterns of C-reactive protein RATIO response in severe community-acquired pneumonia: a cohort study. Crit Care 2012;16(02):R53

34 Schroeder S, Hochreiter M, Koehler T, et al. Procalcitonin (PCT)guided algorithm reduces length of antibiotic treatment in surgical intensive care patients with severe sepsis: results of a prospective randomized study. Langenbecks Arch Surg 2009;394 (02):221-226

35 Hochreiter M, Köhler T, Schweiger AM, et al. Procalcitonin to guide duration of antibiotic therapy in intensive care patients: a randomized prospective controlled trial. Crit Care 2009;13(03): R83

36 Nobre V, Harbarth S, Graf JD, Rohner P, Pugin J. Use of procalcitonin to shorten antibiotic treatment duration in septic patients: a randomized trial. Am J Respir Crit Care Med 2008;177(05):498-505

37 Bouadma L, Luyt CE, Tubach F, et al; PRORATA trial group. Use of procalcitonin to reduce patients' exposure to antibiotics in intensive care units (PRORATA trial): a multicentre randomised controlled trial. Lancet 2010;375(9713):463-474

38 Schuetz P, Briel M, Christ-Crain M, et al. Procalcitonin to guide initiation and duration of antibiotic treatment in acute respiratory infections: an individual patient data meta-analysis. Clin Infect Dis 2012;55(05):651-662

39 Jensen JU, Hein L, Lundgren B, et al; Procalcitonin And Survival Study (PASS) Group. Procalcitonin-guided interventions against infections to increase early appropriate antibiotics and improve survival in the intensive care unit: a randomized trial. Crit Care Med 2011;39(09):2048-2058

40 Karlsson S, Heikkinen M, Pettilä V, et al; Finnsepsis Study Group. Predictive value of procalcitonin decrease in patients with severe sepsis: a prospective observational study. Crit Care 2010;14(06):R205

41 Schuetz P, Amin DN, Greenwald JL. Role of procalcitonin in managing adult patients with respiratory tract infections. Chest 2012;141(04):1063-1073

42 Schuetz P, Maurer P, Punjabi V, Desai A, Amin DN, Gluck E. Procalcitonin decrease over 72 hours in US critical care units predicts fatal outcome in sepsis patients. Crit Care 2013;17 (03):R115

43 Schuetz P, Birkhahn R, Sherwin R, et al. Serial procalcitonin predicts mortality in severe sepsis patients: results from the multicenter procalcitonin MOnitoring SEpsis (MOSES) study. Crit Care Med 2017;45(05):781-789

44 Schuetz P, Hausfater P, Amin D, et al; TRIAGE Study group. Biomarkers from distinct biological pathways improve early risk stratification in medical emergency patients: the multinational, prospective, observational TRIAGE study. Crit Care 2015;19:377

45 Kumar A, Roberts D, Wood KE, et al. Duration of hypotension before initiation of effective antimicrobial therapy is the critical determinant of survival in human septic shock. Crit Care Med 2006;34(06):1589-1596

46 Kumar A, Ellis P, Arabi Y, et al; Cooperative Antimicrobial Therapy of Septic Shock Database Research Group. Initiation of inappropriate antimicrobial therapy results in a fivefold reduction of survival in human septic shock. Chest 2009;136(05):1237-1248

47 Ohl CA, Luther VP. Antimicrobial stewardship for inpatient facilities. JHosp Med 2011;6:S4-S15 
48 Lawrence KL, Kollef MH. Antimicrobial stewardship in the intensive care unit: advances and obstacles. Am J Respir Crit Care Med 2009;179(06):434-438

49 de Jong E, van Oers JA, Beishuizen A, et al. Efficacy and safety of procalcitonin guidance in reducing the duration of antibiotic treatment in critically ill patients: a randomised, controlled, open-label trial. Lancet Infect Dis 2016;16(07):819-827

50 Schuetz P, Wirz Y, Sager R, et al. Effect of procalcitonin-guided antibiotic treatment on mortality in acute respiratory infections: a patient level meta-analysis. Lancet Infect Dis 2018;18(01):95-107

51 Schuetz P, Chiappa V, Briel M, Greenwald JL. Procalcitonin algorithms for antibiotic therapy decisions: a systematic review of randomized controlled trials and recommendations for clinical algorithms. Arch Intern Med 2011;171(15):1322-1331

52 Schuetz P, Briel M, Christ-Crain M, et al. Procalcitonin to guide initiation and duration of antibiotic treatment in acute respiratory infections: an individual patient data meta-analysis. Clin Infect Dis 2012;55(05):651-662

53 Landman GW, Kleefstra N. Procalcitonin in intensive care units: the PRORATA trial. Lancet 2010;375(9726):1606, author reply 1606-1607

54 Wirz Y, Meier MA, Bouadma L, et al. Effect of procalcitonin-guided antibiotic treatment on clinical outcomes in intensive care unit patients with infection and sepsis patients: a patient-level metaanalysis of randomized trials. Crit Care 2018;22(01):191

55 Wirz Y, Branche A, Wolff M, et al. Management of respiratory infections with use of procalcitonin: moving toward more personalized antibiotic treatment decisions. ACS Infect Dis 2017;3 (12):875-879

56 Meier MA, Branche A, Neeser OL, et al. Procalcitonin-guided antibiotic treatment in patients with positive blood cultures: A patient-level meta-analysis of randomized trials. Clin Infect Dis 2018;69(03):388-396

57 Schuetz P, Bolliger R, Merker M, et al. Procalcitonin-guided antibiotic therapy algorithms for different types of acute respiratory infections based on previous trials. Expert Rev Anti Infect Ther 2018;16(07):555-564

58 Huang DT, Yealy DM, Filbin MR, et al; ProACT Investigators. Procalcitonin-guided use of antibiotics for lower respiratory tract infection. N Engl J Med 2018;379(03):236-249

59 Broyles MR. Impact of procalcitonin-guided antibiotic management on antibiotic exposure and outcomes: real-world evidence. Open Forum Infect Dis 2017;4(04):ofx213

60 Caironi P, Latini R, Struck J, et al; ALBIOS Study Investigators. Circulating biologically active adrenomedullin (bio-ADM) predicts hemodynamic support requirement and mortality during sepsis. Chest 2017;152(02):312-320

61 Christ-Crain M, Morgenthaler NG, Struck J, Harbarth S, Bergmann A, Müller B. Mid-regional pro-adrenomedullin as a prognostic marker in sepsis: an observational study. Crit Care 2005;9(06): R816-R824

62 Elke G, Bloos F, Wilson DC, et al; SepNet Critical Care Trials Group. The use of mid-regional proadrenomedullin to identify disease severity and treatment response to sepsis - a secondary analysis of a large randomised controlled trial. Crit Care 2018;22(01):79

63 Mebazaa A, Geven C, Hollinger A, et al; AdrenOSS-1 study investigators. Circulating adrenomedullin estimates survival and reversibility of organ failure in sepsis: the prospective observational multinational Adrenomedullin and Outcome in Sepsis and Septic Shock-1 (AdrenOSS-1) study. Crit Care 2018;22(01):354

64 Gabay C, Kushner I. Acute-phase proteins and other systemic responses to inflammation. N Engl J Med 1999;340(06):448-454

65 Póvoa P, Coelho L, Almeida E, et al. C-reactive protein as a marker of infection in critically ill patients. Clin Microbiol Infect 2005;11 (02):101-108

66 Lelubre C, Anselin S, Zouaoui Boudjeltia K, Biston P, Piagnerelli M. Interpretation of C-reactive protein concentrations in critically ill patients. BioMed Res Int 2013;2013:124021
67 Hernández G, Ospina-Tascón GA, Damiani LP, et al; The ANDROMEDA SHOCK Investigators and the Latin America Intensive Care Network (LIVEN). Effect of a resuscitation strategy targeting peripheral perfusion status vs serum lactate levels on 28-day mortality among patients with septic shock: the ANDROMEDASHOCK randomized clinical trial. JAMA 2019;321(07):654-664

68 Sheyin O, Davies O, Duan W, Perez X. The prognostic significance of troponin elevation in patients with sepsis: a meta-analysis. Heart Lung 2015;44(01):75-81

69 Vallabhajosyula S, Sakhuja A, Geske JB, et al. Role of admission troponin-T and serial troponin-T testing in predicting outcomes in severe sepsis and septic shock. J Am Heart Assoc 2017;6(09):6

70 Khoury J, Arow M, Elias A, et al. The prognostic value of brain natriuretic peptide (BNP) in non-cardiac patients with sepsis, ultra-long follow-up. JCrit Care 2017;42:117-122

71 Papanikolaou J, Makris D, Mpaka M, Palli E, Zygoulis P, Zakynthinos E. New insights into the mechanisms involved in B-type natriuretic peptide elevation and its prognostic value in septic patients. Crit Care 2014;18(03):R94

72 Wang F, Wu Y, Tang L, et al. Brain natriuretic peptide for prediction of mortality in patients with sepsis: a systematic review and meta-analysis. Crit Care 2012;16(03):R74

73 Poston JT, Koyner JL. Sepsis associated acute kidney injury. BMJ 2019;364:k4891

74 Zhang A, Cai Y, Wang PF, et al. Diagnosis and prognosis of neutrophil gelatinase-associated lipocalin for acute kidney injury with sepsis: a systematic review and meta-analysis. Crit Care 2016;20:41

75 de Geus HR, Betjes MG, Schaick Rv, Groeneveld JA. Plasma NGAL similarly predicts acute kidney injury in sepsis and nonsepsis. Biomarkers Med 2013;7(03):415-421

76 Md Ralib A, Mat Nor MB, Pickering JW. Plasma neutrophil gelatinase-associated lipocalin diagnosed acute kidney injury in patients with systemic inflammatory disease and sepsis. Nephrology (Carlton) 2017;22(05):412-419

77 Beunders R, Struck J, Wu AHB, et al. Proenkephalin (PENK) as a novel biomarker for kidney function. JAppl Lab Med 2017; $2: 400-412$

78 Hollinger A, Wittebole X, François B, et al. Proenkephalin A 119159 (Penkid) is an early biomarker of septic acute kidney injury: the Kidney in Sepsis and Septic Shock (Kid-SSS) study. Kidney Int Rep 2018;3(06):1424-1433

79 Kim H, Hur M, Lee S, et al; GREAT Network. Proenkephalin, neutrophil gelatinase-associated lipocalin, and estimated glomerular filtration rates in patients with sepsis. Ann Lab Med 2017;37 (05):388-397

80 Marino R, Struck J, Hartmann O, et al. Diagnostic and short-term prognostic utility of plasma pro-enkephalin (pro-ENK) for acute kidney injury in patients admitted with sepsis in the emergency department. J Nephrol 2015;28(06):717-724

81 Gando S, Shiraishi A, Yamakawa K, et al; Japanese Association for Acute Medicine (JAAM) Focused Outcomes Research in Emergency Care in Acute Respiratory Distress Syndrome, Sepsis and Trauma (FORECAST) Study Group. Role of disseminated intravascular coagulation in severe sepsis. Thromb Res 2019;178:182-188

82 Simmons J, Pittet JF. The coagulopathy of acute sepsis. Curr Opin Anaesthesiol 2015;28(02):227-236

83 Patel P, Walborn A, Rondina M, Fareed J, Hoppensteadt D. Markers of inflammation and infection in sepsis and disseminated intravascular coagulation. Clin Appl Thromb Hemost 2019;25:1-3. Doi: $10.1177 / 1076029619843338$

84 Hassan EA, Abdel Rehim AS, Ahmed AO, Abdullahtif H, Attia A. Clinical value of presepsin in comparison to hsCRP as a monitoring and early prognostic marker for sepsis in critically ill patients. Medicina (Kaunas) 2019;55(02):55

85 Masson S, Caironi P, Spanuth E, et al; ALBIOS Study Investigators. Presepsin (soluble CD14 subtype) and procalcitonin levels for mortality prediction in sepsis: data from the Albumin Italian Outcome Sepsis trial. Crit Care 2014;18(01):R6 
86 Brodska H, Valenta J, Pelinkova K, et al. Diagnostic and prognostic value of presepsin vs. established biomarkers in critically ill patients with sepsis or systemic inflammatory response syndrome. Clin Chem Lab Med 2018;56(04):658-668

87 Wu CC, Lan HM, Han ST, et al. Comparison of diagnostic accuracy in sepsis between presepsin, procalcitonin, and C-reactive protein: a systematic review and meta-analysis. Ann Intensive Care 2017;7 (01):91

88 Li S, Huang X, Chen Z, et al. Neutrophil CD64 expression as a biomarker in the early diagnosis of bacterial infection: a metaanalysis. Int J Infect Dis 2013;17(01):e12-e23

89 Wang X, Li ZY, Zeng L, et al. Neutrophil CD64 expression as a diagnostic marker for sepsis in adult patients: a meta-analysis. Crit Care 2015;19:245

90 Muzlovic I, Ihan A, Stubljar D. CD64 index on neutrophils can diagnose sepsis and predict 30-day survival in subjects after ventilator-associated pneumonia. JInfect Dev Ctries 2016;10 (03):260-268
91 Donadello K, Scolletta S, Covajes C, Vincent JL. suPAR as a prognostic biomarker in sepsis. BMC Med 2012;10:2

92 Gussen H, Hohlstein P, Bartneck M, et al. Neutrophils are a main source of circulating suPAR predicting outcome in critical illness. J Intensive Care 2019;7:26

93 Koch A, Voigt S, Kruschinski C, et al. Circulating soluble urokinase plasminogen activator receptor is stably elevated during the first week of treatment in the intensive care unit and predicts mortality in critically ill patients. Crit Care 2011;15 (01):R63

$94 \mathrm{Wu} \mathrm{Y,} \mathrm{Wang} \mathrm{F,} \mathrm{Fan} \mathrm{X,} \mathrm{et} \mathrm{al.} \mathrm{Accuracy} \mathrm{of} \mathrm{plasma} \mathrm{sTREM-1} \mathrm{for} \mathrm{sepsis}$ diagnosis in systemic inflammatory patients: a systematic review and meta-analysis. Crit Care 2012;16(06):R229

95 Jedynak M, Siemiatkowski A, Mroczko B, Groblewska M, Milewski R, Szmitkowski M. Soluble TREM-1 serum level can early predict mortality of patients with sepsis, severe sepsis and septic shock. Arch Immunol Ther Exp (Warsz) 2018;66(04): 299-306 